will hereafter equalise this disparity. The parcel post, however, is at present discontinued. P. N. Row

Octoler $\mathrm{I}_{4}$

\section{Science and the Government}

THE reason that the Government has refused to aid "the expedition to observe the approaching eclipse" is, that it is perfectly assured that "men of science and culture" are nothing but a set of lying impostors, and would swindle the public out of thousands of pounds to take an observation which might be sone for $10 /$ and much less. The nation is fast beginning to perceive that astronomy is a monstrous cheat-and the Transit of Venus has no more to do with the distance of the sun than it has with the number of fingers on my hand.

JOHN HAMPDEN

[We congratulate Mr. Lowe on his ally, merely remarking that the same Government which has refused the Eclipse Expedition has granted $20,000 l$. for observations of the Transit of V'enus. Perhaps Mr. Hampden can explain the cause of this inconsistency on the part of the Government. -ED.]

\section{Insects upon a Swallow}

G. H. H. mentions in NATURE of Sept. 22 his having found on a swallow in the month of August two slate-coloured insects. () n the I5th of July last, when hauling a seine net in Studland Bay, near Poole, with some fellow members of the Linnean Society Club, I picked up at the foot of the low cliff a young saud-martin, which had seven of these parasites (Ixodes plumbea) affixed to the skin of the head, giving it the appearance of having a slate-coloured fleshy crest. The poor little bird exhibited the symptoms described by your correspondent. I found it panting and apparently exhausted on the ground, and it remained stationary without making any effort to escape. The fishermen of our crew informed me that they often pick up martins with these ticks adhering to them.

The Waldrons, Croydon, Sept. 26

HENRY LEE

\section{Aurora Borealis}

A FINE aurora was observed here on the evening of the 14th inst., between $8^{\mathrm{h}} 3 \mathrm{O}^{\mathrm{m}}$ and $9^{\mathrm{h}} 4 \mathrm{O}^{\mathrm{m}}$, which, in spite of bright moonlight, nearly equalled the splendour the display of September the 24 th. During the early part of the evening the eastern quarter of the sky was covered with bands of light cirri, which had a general direction of E.N.E. to W.S.W., or nearly at right-angles to the magnetic meridian; it was among these clouds and in the N.E. that the beams of the aurora were first seen. At $9^{\mathrm{h}} \mathrm{O}^{\mathrm{m}}$ a magnificent rose-coloured ray was noticed in the N.N.W., extending from the horizon through $V e g a$ towards the zenith. The three stars, $\zeta$, $є$, and $\delta$, of Ursa Major were for more than ten minutes enveloped in the crimson glow of the aurora.

Bedford, Oct. 18

Thos. G. Elger

\section{NOTES}

WE are glad to be able to state that Dr. Wyville Thomson has entirely recovered from the attack of gastric fever which prevented his taking part in the Porcupine expedition this summer. $\mathrm{He}$ is at present going over the zoological collection brought home in that vessel, at the University of London, with Dr. Carpenter, and he reports some very remarkable additions to his new group of vitreous sponges, mainly from the coast of Spain and Portugal. These, with some others procured by Mr. Saville Kent, in Dr. Marshail Hall's yacht, will nearly double the number of known forms referred to the order. They are no pigmies. One of them forms a lovely lace-like vase upwards of three feet in diameter at the lip !

WE have to add to the list of candidates for the Regius Professorship of Natural History in Edinburgh the name of Joln Anderson, M.D. Edin., F.L.S., director of the Imperial Museum of Natural History, Calcutta. Dr. Anderson was attached as Naturalist to a recent expedition through the north of Burmah, and he is, we understand, now on his way home, bringing with him detailed accounts of the important additions which he is known to have made to science in that expedition.
Members of the University of Cambritge, and all who are interested in the study of physical science, will hear with pleasure of the munificent offer made to the University by its Chancellor, the Duke of Devonshire, contained in the following extract of a letter to the Vice-Chancellor :- "I find in the report, dated Feb. 29, 1869, (sic) of the Physical Science Syndicate, recommending the establishment of a Professor and Demonstrator of Experimental Physics, that the buildings and apparatus required for this department of science are estimated to cost $6,300 l$. I am desirous to assist the University in carrying this recommendation into effect, and shall accordingly be prepared to provide the funds required for the building and apparatus, so soon as the University shall have in other respects completed its arrangements for teaching experimental physics, and shall have approved the plan of the building."

AT the Commencement held on the 12th inst. of the Queen's University in Ireland, the Most Honourable the Marquis of Kildare, the newly-appointed Chancellor of the University, presided. After expressing the deep regret of the University at the death of their first Chancellor, the Earl of Clarendon, to whom the University and Colleges were indebted for much of their prosperity, the Chancellor mentioned that the Senate had decided to establish a special curriculum, in which science should have the predominance, and that the degrees of Bachelor and Doctor in Science would be given to those who passed the examinations in the subjects to be herealter enumerated. He also referred to the exaninations for women carried on by the University-the first of these was held in June last in Belfast and Galway-and mentioned that of thirty-three candidates who presented themselves, twenty-one acquitted themselves to the satisfaction of the examiners.

Mr. M. R. PRYor has been elected to a Fellowship of Natural Science in Trinity College, Cambridge. The examination was conducted by Prof. Liveing, Prof. Michael Foster (the new Prælector of the College), Mr. Trotter, and Mr. Hort, Fellows of the College, was open to all the University, and was on a par with the examinations in classics and mathematics, held at the same time for Fellowships. It is the first occasion that this has been done, and the first time that a Fellowship has been offered in Cambridge for competition in Natural Science. We sincerely trust the plan will be continued in Trinity, and that the example will be followed in other Colleges. It would probably contribute more than any other single thing to promote the study of Natural Science in the University, and give an impetus to it in the various schools throughout the kingdom. We sometimes think the Colleges are scarcely conscious of the power they are capable of exercising in this way, and of the responsibility which necessarily attaches to such power. The questions were of a very high order, and we understand the answers evinced so much power as well as knowledge, that the examiners would gladly have elected more than one candidate. We sincerely congratulate Mr. Pryor on having thus worthily won the highest competitive reward for Natural Science hitherto given in this country.

THE Senate of the Queen's University in Ireland has conferred on William King, M.D., Professor of Geology and Mineralogy in Queen's College, Galway, the honorary degree of Doctor of Science, in consideration of his eminence as a geologist.

THE following lectures in Natural Sciences will be delivered. in Trinity and St. John's Colleges, Cambridge, during the Michaelmas term, 1870 . On Electricity: Mr. Trotter, Trinity. On Chemistry : Mr. Main, St. John's. Instruction in Practical Chemistry will also be given. On Geology-(I) Palæontology; (2) Lyell's Principles of Geology; (3) Elementary Lectures: Mr. Bonney, St. John's. (Students of other Colleges can be admitted to these Lectures by arrangement with their college 